\title{
Method Based on Confidence Radius to Adjust the Location of Mobile Terminals
}

García-Fernández, Juan Antonio; Jurado-Navas, Antonio; Fernández-Navarro, Mariano; Sucevic, Nikola

Published in:

Wireless Personal Communications

Link to article, DOI:

10.1007/s11277-016-3674-1

Publication date:

2017

Document Version

Publisher's PDF, also known as Version of record

Link back to DTU Orbit

\section{Citation (APA):}

García-Fernández, J. A., Jurado-Navas, A., Fernández-Navarro, M., \& Sucevic, N. (2017). Method Based on Confidence Radius to Adjust the Location of Mobile Terminals. Wireless Personal Communications, 94(3), 1123-1146. https://doi.org/10.1007/s11277-016-3674-1

\section{General rights}

Copyright and moral rights for the publications made accessible in the public portal are retained by the authors and/or other copyright owners and it is a condition of accessing publications that users recognise and abide by the legal requirements associated with these rights.

- Users may download and print one copy of any publication from the public portal for the purpose of private study or research.

- You may not further distribute the material or use it for any profit-making activity or commercial gain

- You may freely distribute the URL identifying the publication in the public portal 


\title{
Method Based on Confidence Radius to Adjust the Location of Mobile Terminals
}

Wireless Personal Communications

pp 1-24

Juan Antonio García-Fernández, Antonio Jurado-Navas, Mariano Fernández-Navarro, Nikola Sucevic

Article

First Online: 08 September 2016

DOI (Digital Object Identifier): 10.1007/s11277-016-3674-1

Cite this article as:

García-Fernández, J.A., Jurado-Navas, A., Fernández-Navarro, M. et al. Wireless Pers Commun (2016). doi:10.1007/s11277-016-3674-1

\begin{abstract}
The present paper details a technique for adjusting in a smart manner the position estimates of any user equipment given by different geolocation/positioning methods in a wireless radiofrequency communication network based on different strategies (observed time difference of arrival , angle of arrivals, propagation delay...). The main advantage of our proposal is to improve in a remarkable way the accuracy and to mitigate the adverse effect of multipath and other sources of errors that induce to inaccuracy in the terminals position estimates. Accordingly, the estimation of the geographical positions associated to all reported mobile terminals will be remarkable improved independent on the geolocation technique employed. The proposed method will move each position estimate towards a previously calculated area of confidence in a smart manner. This reduced area of confidence is generated to guarantee that the real position of any mobile terminal is inside it with a $95 \%$ of probability of certainty.
\end{abstract}

\section{Keywords}

Confidence radius Certainty area Multilateration Geolocation UMTS LTE OTDOA Angle of arrival Propagation delay Timing advance RTD Sufficient statistics

\section{References}


2. Technical Specification Group, Radio Access Network. (1999). Liaison statement from ITU-R TG 8/1. CSELT, TSGR\#3(99) 189

3. Lin, H., Juang, R., \& Lin, D. (2005). Validation of an improved location-based handover algorithm using GSM measurement data. IEEE Transactions on Mobile Computing, 4(5), 530-536.

CrossRef (http://dx.doi.org/10.1109/TMC.2005.70)

4. Schiller, J., \& Voisard, A. (2004). Location-based services. Burlington: Morgan Kaufmann.

5. Laitinen, H., Ahonen, S., Kyriazakos, S., Lahteenmaki, J., Menolascino, R., \& Parkkila, S. (2001). Cellular location technology. CELLO Consortium Tech. Rep., Project IST-2000-25382-CELLO.

https://lyle.smu.edu/rajand/courses/8377/papers/e911_recent

(https://yle.smu.edu/rajand/courses/8377/papers/e911\%5frecent). Accessed August 2, 2015 .

6. Gustafsson, F., \& Gunnarsson, F. (2005). Mobile positioning using wireless networks. IEEE Signal Processing Magazine, 22(4), 41-53.

CrossRef (http://dx.doi.org/10.1109/MSP.2005.1458284)

7. Roxin, A., Gaber, J., Wack, M., \& Nait-Sidi-Moh, A. (2007). Survey of wireless geolocation techniques. IEEE Globecom Workshops, pp. 1-9.

8. 3GPP TS 25.305 V3.11.0 (2003-12) Stage 2 funcional specification of User Equipment (UE) positioning in UTRAN (Release 1999).

9. Zhao, Y. (2002). Standardization of mobile phone positioning for $3 \mathrm{G}$ systems. IEEE Communications Magazine, 40(7), 108-116.

CrossRef (http://dx.doi.org/10.1109/MCOM.2002.1018015)

10. Kenington, P., Chepstow, M., Randell, N., \& Alton, H. (2013). Method and apparatus for geolocationg a wireless communication unit. European Patent Application EP 2626719 A2, August 14, 2013.

11. Dupray, D., Goldberg, S. F., LeBlanc, F. W., \& Karr, C. L. (2013). Locating a mobile station and applications therefor. U.S. Patent 2013/o288692 A1, March 15, (2013).

12. Karr, C. L., LeBlanc, F. W., Dupray, D. J. (2005). Locating a mobile station using a plurality of wireless networks and applications therefor. U.S. Patent US 6,952,181 B2, October 4, 2005 .

13. Flanagan, M. J. (2010). Determining differences between base station timing offset for pairs of base stations in asynchronous networks using location estimates. Patent WO 2010083943 A1, July 29, 2010.

14. Soma, P., Boyer, P. A., Mia, R. S. (2014). Time and power based wireless location and method of selecting location estimate solution. U.S. Patent US 8,718,676 B2, May 6, 2014.

15. Thomson, M., Winterbottom, J. (2012). Location measurement acquisition adaptive optimization. U.S. Patent US 8,289,210 B2, October 16, 2012.

16. Weisstein, E. W. (2015). Student's T distribution.

http://mathworld.wolfram.com/Studentst-Distribution.html. Accessed August 2, 2015. 
17. Úbeda, C., Romero, J., \& Ramiro, J. (2010). Evaluation of a time-delay based geolocation algorithm in real UMTS networks. In Fifth international conference on broadband and biomedical communications (IB2Com), pp. 1-4.

18. Kallenberg, O. (1997). Foundations of modern probability. New York: Springer.

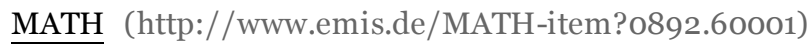

19. Standard Normal Distribution Table.

http://www.stat.tamu.edu/lzhou/stat302/standardnormaltable

(http://www.stat.tamu.edu/lzhou/stat302/standardnormaltable).

20. 3GPP TS 36.355 V9.0.o (2013) LTE; Evolved Universal Terrestrial Radio Access (EUTRA); LTE Positioning Protocol (LPP) (Release 9, 2013).

21. Jurado-Navas, A., García-Fernández, J.A., Fernández-Navarro, M., Úbeda, C. (2014). Location of terminals in a communications network. European Patent PCT/EP2014/o54875, March 12, 2014.

22. García-Fernández, J. A., Jurado-Navas, A., Fernández-Navarro, M., \& Ubeda, C. (2015). Efficient star-topology solving local minima for geolocation in real UMTS networks: An experimental assessment with real data. Wireless Personal Communications. 10.1007/s11277-015-2895-z (http://dx.doi.org/10.1007/s11277015-2895-Z).

23. García-Fernández, J. A., Jurado-Navas, A., Fernández-Navarro, M., \& Úbeda, C. (2015). Experimental assesment of a novel geolocation algorithm base don OTDOA technique in real UMTS networks. Journal of Automation and Control Engineering, 3(5), 435-4411.

CrossRef (http://dx.doi.org/10.12720/joace.3.5.435-441)

24. García-Fernández, J. A., Jurado-Navas, A., Fernández-Navarro, M., \& Úbeda, C. (2015). A comparative study between iterative algorithms for TDOA based geolocation techniques in real UMTS networkds. Submitted for publication.

\section{Copyright information}

(C) Springer Science+Business Media New York 2016

\section{About this article}

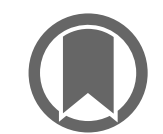

Print ISSN

Online ISSN

0929-6212

1572-834X

Publisher Name

springer US

About this journal

Reprints and Permissions

\section{SPRINGER NATURE}

(C) 2016 Springer International Publishing. Part of Springer Nature.

Not logged in · Not affiliated · 90.185.108.253 